Available online at https://jurnal.stmikroyal.ac.id/index.php/jurdimas

\title{
DESAIN PELATIHAN MENGGAMBAR ORNAMEN BALI SEBAGAI IMPLEMENTASI NILAI PENDIDIKAN AGAMA HINDU
}

\author{
I Wayan Agus Gunada ${ }^{1}$, Ida Bagus Kade Yoga Pramana ${ }^{1}$ \\ ${ }^{1}$ Pendidikan Agama Hindu, Sekolah Tinggi Agama Hindu Negeri Gde Pudja Mataram \\ Email: *gunadastahngpmataram@gmail.com
}

\begin{abstract}
Hindus in Rincung village still have blood and Balinese descent, so of course, they still carry Balinese culture in the daily life of their people, based on the results of interviews that children know Balinese ornaments but are not yet proficient at drawing them so that through the training process of drawing Balinese ornaments to children in Rincung village to introduce and preserve Hindu cultural values, namely Balinese ornaments as a legacy of ancestral art. Community service is part of the Tri Dharma of Higher Education, through dedication, the theory in the education process is implemented through activities in the community that are beneficial and support community development. The purpose of this paper is to describe one of the programs in community service implemented by the Hindu Religious Education study program, STAHN Gde Pudja Mataram in Pasraman Amerta Sanjiwani, Rincung village, namely training in drawing Balinese ornaments. The method used in this service is training which includes the process of planning implementation and evaluation. Based on this dedication activity, the results showed that the children in training to draw Balinese ornaments were very enthusiastic and began to arise motivation to continue to preserve the cultural heritage of their ancestors. Through training activities on community service, this can be used as insight and source of information and can be continued in further service activities.
\end{abstract}

Keywords : devotion; drawing; hindu; learning; ornament

\begin{abstract}
Abstrak: Umat Hindu di desa Rincung masih berdarah dan keturunan suku Bali sehingga tentu masih membawa budaya Bali dalam keseharian masyarakatnya, berdasarkan hasil wawancara bahwa anak-anak mengenal ornamen Bali namun belum mahir untuk menggambarnya sehingga melalui proses pelatihan menggambar ornamen Bali pada anak-anak di desa Rincung untuk mengenalkan dan melestarikan kembali nilai-nilai budaya yang bernuansa Hindu yaitu ornamen Bali sebagai warisan kesenian leluhur. Pengabdian kepada masyarakat bagian dari Tri Dharma Perguruan Tinggi, melalui pengabdian maka teori dalam proses Pendidikan diimplementasikan melalui kegiatan di masyarakat yang bermanfaat dan menunjang pembangunan masyarakat. Tujuan penulisan ini adalah menggambarkan salah satu program dalam pengabdian kepada masyarakat yang dilaksanakan oleh program studi Pendidikan Agama Hindu, STAHN Gde Pudja Mataram di Pasraman Amerta Sanjiwani desa Rincung yaitu pelatihan menggambar ornamen Bali. Metode yang digunakan dalam pengabdian ini adalah pelatihan yang meliputi proses perencanaan pelaksanaan dan evaluasi. Berdasarkan kegiatan pengabdian ini maka didapatkan hasil bahwa anak-anak dalam pelatihan menggambar ornamen Bali sangatlah antusias dan mulai timbul motivasi untuk terus melestarikan warisan budaya leluhurnya. Melalui kegiatan pelatihan pada pengabdian kepada masyarakat ini dapat dijadikan sebagai suatu wawasan dan sumber informasi dan dapat dilanjutkan kembali dalam kegiatan pengabdian selanjutnya.
\end{abstract}

Kata Kunci : hindu; menggambar; ornamen; pembelajaran; pengabdian 
Available online at https://jurnal.stmikroyal.ac.id/index.php/jurdimas

\section{PENDAHULUAN}

Tri Dharma Peguruan Tinggi merupakan suatu kewajiban yang harus dilakukan oleh institusi Pendidikan Tinggi. Sekolah Tinggi Agama Hindu Negeri Gde Pudja Mataram sebagai institusi Pendidikan tinggi keagamaan Hindu dibawah Kementerian Agama turut pula melaksanakan tri dharma sebagai kewajiban dalam penyelenggaraan proses pendidikannya. Visi Misi STAHN Gde Pudja Mataram adalah sebagai pusat kajian agama Hindu yang unggul dan berdaya saing, memiliki misi yaitu melaksanakan Pendidikan yang berbasis budaya Hindu, Iptek dan Seni, mengembangkan pola berpikir ilmiah dalam penelitian dan pengkajian Hindu, melaksanakan pengabdian masyarakat sebagai wahana aplikasi bidang keilmuan dan memupuk kepekaan terhadap lingkungan.

Berdasarkan hal tersebut, melalui visi dan misi yang sudah dirumuskan oleh STAHN Gde Pudja Mataram maka pengabdian kepada masyarakat dilakukan dengan berlandaskan diri kepada ajaranajaran agama Hindu sehingga terjadi transfer keilmuan dan transformasi pengetahuan dan teori kedalam praktek nyata yang memberikan manfaat dan ikut berperan dalam menunjang pembangunan di masyarakat. Masyarakat desa Rincung merupakan umat Hindu yang masih memiliki garis keturunan suku Bali sehingga secara tidak langsung maka budaya Bali sebagai budaya warisan leluhur tentu masih menjadi landasan keseharian dalam hidup masyarakat, sehingga dengan pelatihan menggambar ragam hias Bali ini turut memberikan pengetahuan kepada generasi umat Hindu untuk mengenal dan setidaknya mampu untuk menggambar secara sederhana ragam hias tersebut sebagai bagian pelestarian budaya leluhur. Melalui pengabdian kepada masyarakat diharapkan dapat memberikan manfaat khususnya bagi umat Hindu.

Pandemi Covid-19 yang sedang mewabah tidak menyurutkan semangat dari Lembaga untuk tetap berpartisipasi dalam proses pembangunan umat Hindu, namun pelaksanaan pengabdian tersebut dilakukan tetap berpegangan dan berdasarkan regulasi pada protokol Kesehatan sebagai bentuk partisipasi dalam memutus rantai penyebaran virus Covid-19. Sebagaimana yang sudah diketahui bahwa virus Covid-19 merupakan semacam virus baru yang bermutasi dan dapat dikategorikan sebagai penyakit baru, penyebaran virus yang sangat cepat sangat harus diwaspadai karena sampai saat ini belum ada pengobatan yang dapat dilakukan untuk menyembuhkan penyakit yang disebabkan oleh virus Covid-19 (Susilo, 2020).

Dalam hasil rapat tim pengabdian kepada masyarakat maka diputuskan bahwa dalam prosesnya maka tema pengabdian yang disepakati adalah "Implementasi Nilai-nilai Pendidikan Agama Hindu di Era New Norma". Pemilihan tema ini didasarkan atas bidang keilmuan yang dilaksanakan oleh Prodi Pendidikan Agama Hindu yang mengedepankan implementasi nilai-nilai Pendidikan dan ajaran agama Hindu dalam proses pendidikan dan pengajaran.

Kegiatan pengabdian kepada masyarakat ini dibentuk program kerja yang dibina dan dilatih oleh dosen serta mahasiswa yang utamanya berorientasi dalam proses-proses pembelajaran agama Hindu, salah satunya adalah kegiatan menggambar ornamen atau ragam hias Bali. Seperti yang diketahui ragam hias Bali merupakan suatu bentuk ornamen yang merupakan ciri khas dari karya seni 
Available online at https://jurnal.stmikroyal.ac.id/index.php/jurdimas

rupa Bali. Ornamen Bali merupakan sebuah karya seni rupa yang diciptakan dan dikreasikan oleh masyarakat Bali, ornamen Bali bukan hanya sekedar sebuah karya seni semata namun didalamnya terkandung nilai-nilai filosofis yang merupakan penyajian kembali kehidupan masyarakat Bali dengan ajaran agama Hindu yang merupakan landasan masyarakat Bali dalam memaknai hidupnya ini terlihat dalam penempatan ornamen Bali yang sering ditemukan di arsitektur suci seperti pura, dan memiliki nilai-nilai ajaran suci didalamnya (Maharlika, 2018).

Berdasarkan kajian-kajian pustaka terkait hasil penelitian sebelumnya mengenai kegiatan terkait pelatihan menggambar ragam hias ditemukan beberapa hasil penelitian relevan. (Gunada, 2020) menegaskan bahwa seni lukis tradisional Bali merupakan hasil karya seni rupa yang memiliki karakteristik khas Bali yang masih berkembang hingga sekarang dimana dalam karyanya tidak hanya sekedar karya seni semata namun terkandung ajaran-ajaran suci sebagai media transfer dan transformasi nilai ajaran agama Hindu.

(Abidin, 2016) menyebutkan menggambar ragam hias sebagai tema sangat berpengaruh dan menunjang hasil prestasi siswa terkait pembuatan mozaik. Penerapan ragam hias dalam tugas menggunakan media bambu memberikan hasil belajar yang baik dan berdampak kepada semakin termotivasinya siswa dalam mempelajari mata pelajaran seni budaya (Sari \& Mainur, 2017). Kemudian lebih lanjut disebutkan (Sarinah \& Azmi, 2019) bahwa penerapan prinsip-prinsip seni rupa dalam pembelajaran penerapan ragam hias memperoleh hasil yang cukup baik.
Berdasarkan hasil perbandingan terhadap penelitian sebelumnya terdapat perbedaan dengan kegiatan yang dilakukan kini yaitu objek penerapan dalam kegiatan ini adalah penerapan ragam hias Bali yang memiliki karakteristik tersendiri, perbedaan yang kedua yaitu bahwa sasaran pelatihan merupakan anak-anak yang belajar secara nonformal di pasraman yaitu Pasraman Amerta Sanjiwani sehingga proses pembelajaran lebih menekankan kepada implementasi nilai-nilai Pendidikan Agama Hindu.

Tidak hanya itu pasraman sebagai Lembaga Pendidikan Hindu merupakan suatu institusi pendidikan nonformal keagamaan yang menunjang proses Pendidikan agama Hindu. Pasraman sebagai Lembaga Pendidikan merupakan suatu institusi alternatif dimana proses pendidikan agama dalam lembaga formal yang menekankan kepada kecerdasan kognitif, sedangkan pasraman lebih menekankan kepada penekanan kecerdasan afektif dan psikomotorik yaitu menekankan kepada transformasi ajaran agama Hindu pada pengembangan sikap dan keterampilan sehingga terjadi sinergi antara sekolah sebagai lembaga formal dan pasraman sebagai lembaga nonformal untuk menginternalisasi Pendidikan karakter bagi peserta didik yang berlandaskan ajaran agama Hindu (Subagia, 2016).

Program pengabdian kepada masyarakat ini juga memiliki manfaat untuk ikut mengembangkan kemampuan psikomotorik bagi siswa sehingga memiliki keterampilan yang kedepannya dapat diasah dan dikembangkan sehingga memiliki potensi di bidang pendidikan seni Hindu sebagai usaha dalam pelestarian warisan budaya leluhur. 
Available online at https://jurnal.stmikroyal.ac.id/index.php/jurdimas

\section{METODE}

Pelaksanaan pengabdian dilaksanakan di Pasraman Amerta Sanjiwani yang terletak di desa Rincung yang termasuk kedalam wilayah kabupaten Lombok Barat. Metode yang digunakan adalah pelatihan dengan mengedepankan prinsip dan pendekatan kualitatif, dimana studi yang digunakan adalah studi fenomenologi sebagai suatu kajian pada bidang filsafat, namun perkembangan kemudian membuat fenomenologi menjadi suatu studi dalam sebuah metode riset yang melihat suatu fenomena atau gejala yang berada didalam masyarakat (Hasbiansyah, 2008). Pendekatan fenomenologi sebagai sebuat metode riset memfokuskan perhatian kepada suatu gejala baik kejadian maupun peristiwa yang proses penilaian terhadap gejala tersebut bersifat subyektif (Nuryana, Pawito, \& Utari, 2019). Teknik pengumpulan data yang digunakan adalah dengan Teknik observasi yaitu observasi sebelum kegiatan pengabdian dilakukan dan selama pengabdian dilakukan, wawancara dengan pengelola Pasraman Amerta Sanjiwani dan anak-anak sebagai subjek pelatihan dalam kegiatan pengabdian dan teknik yang ketiga adalah kajian pustaka yaitu mengkaji pustaka-pustaka yang relevan dalam penelitian ini. Kegiatan pengabdian kepada masyarakat yang bertemakan "Implementasi Nilai-Nilai Pendidikan Agama Hindu di Era New Normal" sendiri dilakukan melalui proses perencanaan yang matang. Pemilihan tempat sudah disesuaikan dengan sasaran keilmuan dalam Prodi Pendidikan Agama Hindu. Kegiatan ini dirancang dalam tiga proses yaitu perencanaan dilakukan dengan menentukan lokasi, program kerja dan survey lokasi. Proses yang kedua dilakukan dengan membuat rancangan desain pelatihan dan melaksanakan segala program kerja yang telah disusun, dan proses yang ketiga adalah evaluasi, dilakukan dengan melihat sejauh mana anak-anak sebagai subjek pelatihan berhasil memahami materi pelatihan dengan beberapa instrumen penilaian dan wawancara kepada peserta pelatihan terkait manfaat dan kendala yang dihadapi dalam pembinaan pelatihan menggambar ornamen Bali.

\section{PEMBAHASAN}

Model ADDIE merupakan salah satu model desain pembelajaran dalam rancangan pelatihan yang umum dilakukan, ADDIE merupakan singkatan dari Analyze, Design, Development, Implement dan Evaluation (Tung, 2017).

\section{Analyze (menganalisis kebutuhan dan tujuan pelatihan menggambar ornamen Bali)}

Berdasarkan hasil observasi dan survey bahwa dalam proses pembelajaran menekankan nilai-nilai Pendidikan agama Hindu dan siswa yang belajar umumnya siswa Sekolah Dasar kelas 3. Melalui kegiatan ini maka adanya suatu transfer ilmu dan transformasi nilai ajaran agama Hindu dalam menguatkan sradha dan bhakti umat khususnya bagi siswa pasraman dalam membangun karakter bagi anak-anak Hindu melalui internalisasi dan penguatan konsep ajaran agama Hindu.

Melalui hasil survey tersebut maka panitia kemudian merumuskan program kerja yang disesuaikan dengan kebutuhan pembelajaran di Pasraman Amerta Sanjiwani salah satunya adalah pelatihan menggambar ornamen Bali. 
Available online at https://jurnal.stmikroyal.ac.id/index.php/jurdimas

Tujuan dari pelatihan ini adalah mengenalkan kepada anak-anak di Pasraman Amerta Sanjiwani terkait teori dan praktek dalam menggambar ornamen Bali dan ikut melestarikan warisan budaya leluhur

\section{Design (rancangan pelatihan)}

Desain rancangan disesuaikan dengan kondisi dan situasi pada lokasi pengabdian dan memperhatikan pula kondisi akibat pandemi Covid-19 sehingga tidak terjadinya pelanggaran atas perintah pelaksanaan protokol kesehatan. Tujuan pelatihan yaitu pengenalan ornamen Bali melalui pelatihan menggambar, dengan Kompetensi Akhir siswa didik pasraman usia 8-9 tahun mampu untuk memahami teori dan membuat ornamen Bali sederhana kaketusan berupa bentuk kakul-kakulan dan mas-masan.

Strategi dan metode pembelajaran langsung atau Direct Instructional dimana pembina memberikan materi ornamen Bali, kemudian melaksanakan pembimbingan dalam proses pelatihan, refleksi atas materi pelatihan dan evaluasi hasil pelatihan dengan menerapkan sistem reward menyeluruh bagi peserta pelatihan sebagai bentuk motivasi dan apresiasi sehingga tumbuh minat bagi peserta untuk melanjutkan dan mengembangkan materi yang diberikan.

\section{Development \\ (mengembangkan pelatihan sesuai tujuan dan rancangan)}

Dalam proses pengembangan pelatihan maka hasil analisis dan desain menjadi dasar dalam penentuan konten dalam pengembangan pelatihan. Adapun konten pelatihan adalah sebagai berikut : Ornamen Bali merupakan suatu ciri ragam hias yang memiliki karakteristik stilirisasi bentuk alam bukan hanya tumbuhan namun juga hewan serta bentuk alam lain seperti persegi, segitiga dan lain-lain.

Ragam hias Bali secara umum terdiri dari tiga klasifikasi yaitu kaketusan, pepatran dan kekarangan. Kaketusan merupakan ornamen Bali yang merupakan stilirisasi bentuk alam sederhana yang memiliki bentuk geometris yang disusun secara berulang (Suparta, 2010). Contohnya saja kakulkakulan yang merupakan bentuk ornamen sederhana yang merupakan stiliran keong sawah yang memiliki bentuk geometris lingkaran.

Pepatran merupakan bentuk ragam hias Bali stilirasi bentuk daundaunan yang dibentuk sedemikian rupa dan memiliki pola berulang dan berkembang (Maharlika, 2018). Contohnya seperti patra samblung yaitu motif ornamen yang merupakan stiliran bentuk daun-daunan yang merambat dan dibuat dengan pola berulang.

Membuat dan menggambar ornamen Bali salah satunya kaketusan terdapat tiga proses sederhana yaitu membuat bentuk global, kemudian kontur dan cawi. Bentuk global merupakan bentuk dasar dari ornamen Bali yang umumnya berwujud geometris misalkan kakul-kakulan yang berwujud lingkaran yang berulang.

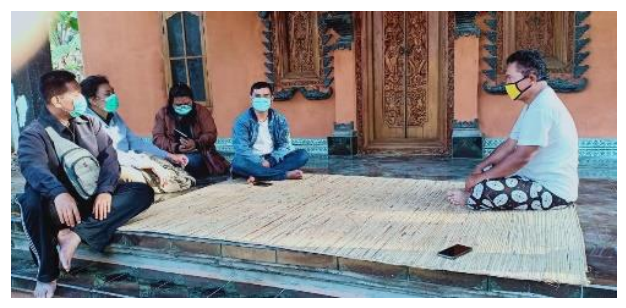

Gambar 1. Pelaksanaan Survey

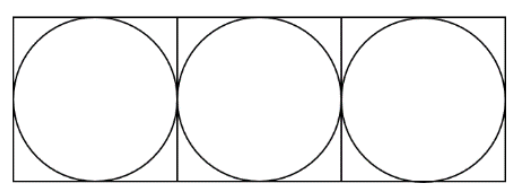

Gambar 2. Pola dasar kakul-kakulan. 
Available online at https://jurnal.stmikroyal.ac.id/index.php/jurdimas

Proses selanjutnya adalah memberikan kontur atau penegasan, umumnya dalam menggambar bentuk global maka akan ditemukan garis yang diulang-ulang sehingga melalui kontur maka bentuk global diberikan penegasan sehingga terbentuklah wujud geometris yang ideal. Dalam pembuatan kaketusan maka masih bisa menggunakan alat bantu seperti penggaris dan jangka sehingga dapat membentuk garis geometris yang rapi dan sempurna.

Proses ketiga adalah memberikan cawi, istilah cawi dapat disedernahakan dengan pemberian ukiran atau ringgit sehingga bentuk global alam yang sederhana kemudian dapat diubah dalam bentuk ragam hias yang cenderung rumit. Penerapan karya gambar ataupun lukis maka proses finishing umumnya diwarna dengan teknik sigar, teknik sigar merupakan teknik pewarnaan yang memfokuskan pewarnaan pada prinsip gradasi warna, sehingga bentuk yang diberikan warna gradasi dapat terkesan memiliki volume dan bertekstur. Teknik sigar terdiri dari sigar hitam putih dan warna, yang umumnya teknis pewarnaan dari warna yang terang perlahan ke gelap ataupun sebaliknya

\section{Implement (proses pelaksanaan)}

Proses pelaksanaan dari pelatihan menggambar ragam hias Bali pada kegiatan pengabdian kepada masyarakat sendiri dilakukan secara formal setelah proses pembukaan kegiatan pengabdian secara resmi pada Pasraman Amerta Sanjiwani pada tanggal 18 September 2020.

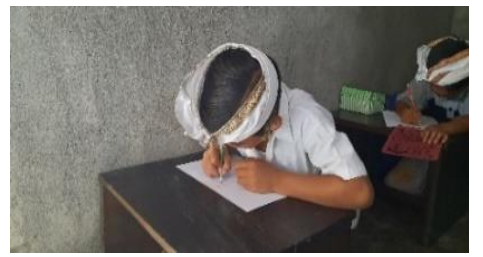

Gambar 3. Proses sketsa
Sasaran peserta pelatihan yang secara jenjang masih pada tahap peserta didik sekolah dasar maka proses pelaksanaan lebih mengedepankan aspek proses pembelajaran langsung dengan materi yang menarik dan penggunaan Bahasa yang sederhana sehingga anakanak dapat mengerti apa yang disampaikan oleh Pembina. Proses dilakukan dengan membagi dua kelompok yaitu kelompok A berjumlah 9 orang dan kelompok B berjumlah 9 orang ini dilakukan sebagai bentuk pelaksanaan protokol Kesehatan yaitu pengaturan jarak fisik.

Setelah proses pemberian materi maka selanjutnya adalah pembimbingan secara langsung, maka Pembina selaku tutor dalam pelatihan ini mencontohkan proses awal dari pembuatan ornamen Bali langkah demi langkah. Ornamen Bali yang dijadikan sebagai bahan pelatihan adalah ornamen kaketusan kakul-kakulan karena bentuk yang sederhana sehingga tidak terlalu sulit jika dipelajari oleh peserta didik usia 8-9 tahun.

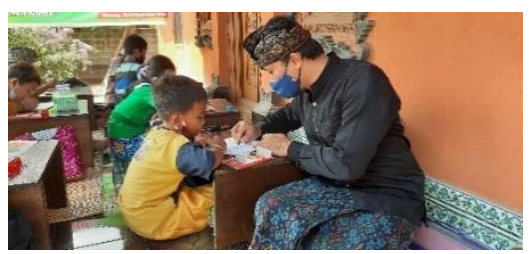

Gambar 4. Pembimbingan oleh Pembina

Pada akhir pelatihan maka hasilhasil karya dari peserta pelatihan dikumpulkan untuk dinilai, penilaian menggunakan format penilaian dengan beberapa instrument sederhana. Hasil karya peserta pelatihan dinilai dan diberikan peringkat sebagai bentuk motivasi dan reward uniknya dalam proses pelatihan ini seluruh peserta di berikan reward meliputi tiga kategori yaitu juara umum 1,2,3, juara favorit 
Available online at https://jurnal.stmikroyal.ac.id/index.php/jurdimas

1,2,3 dan juara harapan 1,2,3 baik kelompok A dan kelompok B. Reward sendiri diberikan pada penutupan Kegiatan Pengabdian Kepada Masyarakat.

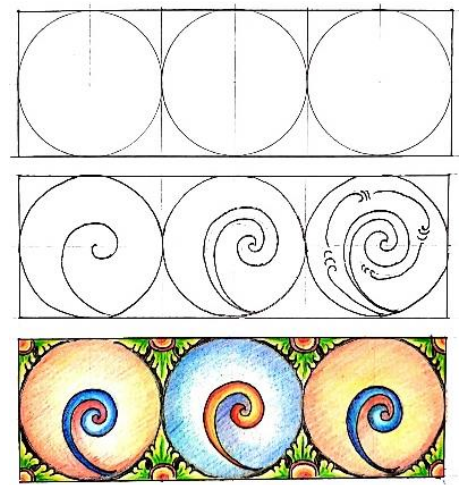

Gambar 5. Hasil karya salah satu peserta pelatihan

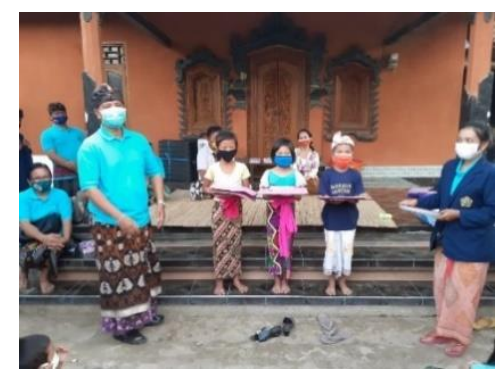

Gambar 6. Penerimaan hadiah oleh peserta sebagai reward dalam pelatihan

Tabel 1. Instrumen Penilaian

\begin{tabular}{llll}
\hline No & Instrumen & Nilai & $\begin{array}{l}\text { Persent } \\
\text { ase }\end{array}$ \\
\hline 1 & $\begin{array}{l}\text { Kesesuaian } \\
\text { Bentuk }\end{array}$ & $1-40$ & $40 \%$ \\
\hline 2 & keindahan & $1-30$ & $30 \%$ \\
\hline 3 & Kebersihan & $1-15$ & $15 \%$ \\
\hline 4 & Kerapian & $1-15$ & $15 \%$ \\
\hline & Jumlah & 100 & $100 \%$ \\
\hline & Nilai Akhir & I1+I2+I3+I4=NA \\
\hline
\end{tabular}

\section{Evaluation atau evaluasi pelatihan menggambar ornamen Bali}

Berdasarkan hasil pelaksanaan kegiatan pelatihan menggambar ornamen Bali ini baik dari proses perencanaan perancangan desain pelatihan dan pelaksanaan maka didapatkan hasil evaluasi yaitu pelaksanaan pelatihan sudah berjalan dengan lancar, setiap peserta didik sudah mampu untuk membuat ragam hias Bali kakul-kakulan secara sederhana dan adanya antusiasme oleh peserta pelatihan.

Selain hal itu terdapat pula kendala dan hambatan yaitu hambatan karena adanya pandemi Covid-19 membuat proses pelatihan kurang efektif dan efisien dan waktu yang terbilang sangat singkat membuat pelatihan menjadi kurang maksimal.

\section{SIMPULAN}

Berdasarkan hasil pengabdian kepada masyarakat terkait pelatihan menggambar ornamen Bali telah berjalan sesuai dengan perencanaan dan melalui pelatihan ini peserta didik telah mengetahui teori dan teknik pembuatan ornamen sederhana, terlihat antusiasme dalam proses pelatihan menggambar ragam hias ini terutama karena adanya reward atau penghargaan yang diberikan sehingga memunculkan motivasi untuk bersungguh-sungguh dalam proses pelatihannya. Adanya kendala serta hambatan utamanya pandemi Covid-19 tentu sangat memberikan dampak sehingga proses pelatihan jadi kurang maksimal.

\section{DAFTAR PUSTAKA}

Abidin, M. Z. (2016). Pengaruh Prestasi Menggambar Ragam Hias Terhadap Pembuatan Mozaik Di SMP Negeri 1 Wonoayu. Jurnal Seni Rupa, 4(03). Jurnal Pendidikan Seni Rupa, 04(3), 
Available online at https://jurnal.stmikroyal.ac.id/index.php/jurdimas

484-493. Retrieved From Https://Jurnalmahasiswa.Unesa.A c.Id/Index.Php/Va/Article/View/1 7761

Gunada, I. W. A. (2020). Ajaran Agama Hindu Sebagai Inspirasi Penciptaan Karya Seni Lukis Tradisional Bali Abstrak. Gorga: Jurnal Seni Rupa, 09(1), 158165.

Https://Doi.Org/Https://Doi.Org/1 $0.24114 / \mathrm{Gr} . V 9 \mathrm{i} 1.18492$

Hasbiansyah, O. (2008). Pendekatan Fenomenologi: Pengantar Praktik Penelitian Dalam Ilmu Sosial Dan Komunikasi. Mediator: Jurnal Komunikasi, 9(1), 163-180. Https://Doi.Org/10.29313/Mediat or.V9i1.1146

Maharlika, F. (2018). Studi Multikultural Pada Ornamen Bali Pepatraan: Patra Cina. Serat Rupa Journal of Design, 2(1), 67-77. Https://Doi.Org/10.28932/Srjd.V2 i1.478

Nuryana, A., Pawito, P., \& Utari, P. (2019). Pengantar Metode Penelitian Kepada Suatu Pengertian Yang Mendalam Mengenai Konsep Fenomenologi. Ensains Journal, 2(1), 19-24. Https://Doi.Org/10.31848/Ensains .V2i1.148

Sari, L. P., \& Mainur, M. (2017). PEMBELAJARAN MEMBUAT RAGAM HIAS MENGGUNAKAN MEDIA BAMBU DENGAN METODE DEMONSTRASI PADA SISWA KELAS VII SMP NEGERI 1
TALANG KELAPA. JURNAL SITAKARA, 2(2)., 35-50. Https://Doi.Org/Http://Dx.Doi.Or g/10.31851/Sitakara.V0i0.1192

Sarinah, S., \& Azmi, A. (2019). Analisis Hasil Menggambar Ragam Hias Melayu Ditinjau Dari PrinsipPrinsip Seni Rupa Karya Siswa Di Smp Kartika I-1 Medan. Gorga: Jurnal Seni Rupa, 8(2), 284. Https://Doi.Org/10.24114/Gr.V8i 2.14655

Subagia, I. N. (2016). Keberadaan Pasraman Sebagai Penguatan Budaya Lokal Dikaitkan Dengan Peraturan Pemerintah No 55 Tahun 2007. Vidya Samhita Jurnal Penelitian Agama, 2(2), 44-68. Retrieved From Https://Ejournal.Ihdn.Ac.Id/Index .Php/Vs/Article/View/172

Suparta, I. M. (2010). Jenis Hiasan Tatahan Bade. Imaji : Jurnal Seni Dan Pendidikan Seni, 8(1), 8191.

Https://Doi.Org/Https://Doi.Org/1 0.21831/Imaji.V8i1.6651

Susilo, A., Rumende, C. M., Pitoyo, C. W., Santoso, W. D., Yulianti, M., Sinto, R., ... Cipto, R. (2020). Coronavirus Disease 2019: Tinjauan Literatur Terkini. Jurnal Penyakit Dalam Indonesia, 7(1), 45-67.

Https://Doi.Org/Http://Dx.Doi.Or g/10.7454/Jpdi.V7i1.415

Tung, K. Y. (2017). Desain Instruksional; Perbandingan Model \& Implementasinya. Yogyakarta: CV. Andi Offset. 